\title{
Native or seeded rangeland for cows with high or low milk production
}

\author{
DON C. ADAMS, ROBERT B. STAIGMILLER, BRADFORD W. KNAPP, AND JAMES \\ B. LAMB
}

\begin{abstract}
Adams is associate professor and Lamb is a research associate, University of Nebraksa, Institute of Agriculture and Natural Resources, West Central Research and Extension Center, Route 4, Box 46A, North Platte 69101; Staigmiller and Knapp are research physiologist and statistician, respectively, USDA-ARS Ft. Keogh Livestock and Range Research Laboratory, Miles City, Mont. 59031. Adams was formerly with USDA-ARS.
\end{abstract}

\begin{abstract}
Multiparous cows ( $n=91,1986 ; n=92,1987)$ were selected from 2 populations to obtain cattle with high and low milk production. After March-April calving, high and low producing cows grazed either native range (treatment 1) or seeded range (treatment 2) until weaning in September. Seeded range included paddocks of crested wheatgrass (Agropyron desertorum, Fisch. ex [Link]Schult), contour furrowed native range interseeded with "Ladak" alfalfa (Medicago Sativa L.), and Russian wildrye grass (Psathrostachys juncea [Fisch.] Nevski.). In treatment 2, crested wheatgrass was grazed mid-April to 17 June, followed by contour furrowed rangeland 18 June to 5 August, and ended with Russian wildrye 6 August to weaning (mid-September). Data were analyzed as a split plot with treatment and year in the main plot and cow type in the subplot. Number of cows exhibiting estrus before the beginning of the breeding season and fall pregnancy rate were not influenced $(P>0.05)$ by range treatment. Twelve-hour milk production during May, June, August, and September ranged from 11.3 to $6.8 \mathrm{~kg}$ and 7.6 to $3.9 \mathrm{~kg}$ for high and low producing cows, respectively. Cows with high milk production lost body condition during and after the breeding season, whereas cows with low milk production maintained body condition during the same period. Live weight gain of calves was greater $(P<0.01)$ for cows with high production than cows with low production but was not affected $(P>0.05)$ by range treatment. We concluded that native and seeded ranges were of similar nutritive value for cows with high and low milk production and that cows with high milk production may have greater nutrient requirements during late summer-early fall than what was provided by native or seeded ranges. Protein may be the primary limiting nutrient in forages during the late summer for lactating cows grazing Northern Great Plains range.
\end{abstract}

Key Words: reproduction, crested wheatgrass, Russian wildrye grass, contour furrows, body condition

Nutrient requirements of a lactating cow increase as milk production increases (NRC 1984). High milk production in a spring calving system may contribute to a negative nutrient balance of the cow during spring and late summer months on Northern Great Plains rangeland (Adams and Short 1987). Loss of body condition after calving may reduce pregnancy rate in the cow herd, especially if cows are thin at calving (Richards et al. 1986). Seeded rangeland grazed in combination with native rangeland has been evaluated as a means to improve nutrient status of lactating cows (Houston and Urick 1972, Hart et al. 1983, Adams et al. 1989). Some improvement in reproduction and weaning weights were observed from

Published with the approval of the director of the Montana Agr. Exp. Sta., Journal Ser. J2827, and director of the Nebraska Agr. Res. Div. as Journal Series 10171.

Manuscript accepted 24 Apr. 1993. seeded rangeland (Houston and Urick 1972, Adams et al. 1989), but the primary benefits have been increased stocking rate and flexibility in managing native rangeland in the early spring (Hart et al. 1983, Adams et al. 1989). Studies evaluating seeded and native range forage have not accounted for differing levels of animal production. Individual animal performance of high producing beef cows may be improved by grazing seeded range during lactation. It has been observed that: (1) crested wheatgrass (Agropyron desertorum, Fisch. ex [Link] Schult.) was ready for spring grazing 10 days to 5 weeks earlier than native species (Houston and Urick 1972), (2) contour furrowing allows establishment of legumes in native rangeland (Adams et al. 1989), and (3) Russian wildrye (Psathrostachys juncea [Fisch.] Nevski) maintains high forage quality during the late summer and fall (Wight et al. 1983).

Our objectives were to determine: (1) if individual animal performance of spring calving cows with high or low milk production was different when grazing native versus seeded rangeland, and (2) if interactions existed between range treatment and level of milk production.

\section{Materials and Methods}

After calving in 1986 and 1987, multiparous cows with high or low milk production were assigned to 2 replicated grazing treatments: (1) native rangeland and (2) seeded rangeland. The native rangeland replicates were 2 paddocks of 265 and 194 ha which were grazed continuously throughout the grazing season. Each seeded rangeland replicate consisted of: (1) crested wheatgrass ( $40 \mathrm{ha}$ ); (2) contour furrowed native rangeland (40 ha) interseeded with "Ladak" alfalfa (Medicago Sativa L.); and (3) Russian wildrye grass ( $34 \mathrm{ha}$ ). See Table 1 for description of grazing periods, animal numbers, and stocking rate. Major forage species in the native rangeland paddocks were western wheatgrass (Pascopyrum smithii [Rydb.] Love), blue grama (Bouteloua gracilis [H.B.K.] Lag. ex Griffiths), needle-and-thread grass (Stipa comata Trin. and Rupr.), buffalo grass ( Buchloe dactyloides [Nutt.] Engelm.), green needlegrass (Stipa viridula Trin.), cheatgrass (Bromus tectorum L.), Japanese brome (Bromus japonicus Thunb.), and threadleaf sedge (Carex filifolia Nutt.) Other important species include silver sagebrush ( Artemisia cana Pursh), fringe sagewort (Artemisia frigida Willd.), greasewood (Sarcobatus vermiculatus [Hook.] Emory.), and plains prickly pear (Opuntia polycantha Haw.). Species composition of the contour furrowed native rangeland paddocks was the same as that of native rangeland paddocks with the exception of the interseeded alfalfa. Grazing treatments began each year when crested wheatgrass attained a height of approximately $130 \mathrm{~mm}$ as recommended by Currie and Smith (1970).

Precipitation was recorded about $14 \mathrm{~km}$ from the study site at a weather station operated by the Federal Aviation Administration. 
Table 1. Animal numbers, stocking rate, and dates significant to data collection and management of the animal and range resources.

\begin{tabular}{lll}
\hline & \multicolumn{2}{c}{ Year } \\
\cline { 2 - 3 } Item & 1986 & 1987 \\
\hline \multicolumn{2}{c}{ Animal numbers } \\
\cline { 2 - 3 } Grazing treatment: & 43 & 46 \\
$\quad$ Native range & 48 & 46 \\
$\quad$ Seeded range & 44 & 44 \\
Cow type: & \multicolumn{2}{c}{} \\
$\quad$ Low lactation & 25 & 23 \\
$\quad$ High lactation: & 22 & 25 \\
$\quad$ Red Angus $\times$ Tarentaise & & \\
$\quad$ Red Angus $\times$ Charolais & &
\end{tabular}

Grazing periods

Native range
Seeded range:
Crested wheatgrass
Contour furrowed
Russian wildrye

10 Apr.-16 Sept. 20 Apr.-24 Sept.

10 Apr.-17 Jun. 20 Apr.-17 Jun.

18 Jun.-5 Aug. 18 Jun. -5 Aug.

6 Aug.-16 Sept. 6 Aug.-24 Sept.

Stocking rate, animal unit days/ha rangeland ${ }^{\mathrm{b}}$

Native range
Seeded range:
Crested wheatgrass
Contour furrowed
Russian wildrye
Data collection periods
Prebreeding estrous detection
Breeding season
Weaning
Begin calving
12-h milk production
Diet collections $^{c}$

19.7

52.8

43.2

40.6

22.0

43.3

41.1

51.9
8 Jun.-18 Jun. 8 Jun.-18 Jun.
19 Jun. -5 Aug. 19 Jun. -5 Aug.
20 Sept. 24 Sept.
21 Mar. 29 Mar.

23 May, 18 Jun., 1 Aug., 14 Sept.

12 May, 9 Jun., 7 Jul., 4 Aug., 1 Sept.

${ }^{a}$ Cows and calves

${ }^{b}$ Animal unit days (AUD) includes cow, calves, esophageal steers, and bulls; a $454.5 \mathrm{~kg}$ cow for 1 day = I AUD; 0.1 AUD was added for each $100 \mathrm{~kg}$ cow weight over $454.5 \mathrm{~kg}$ 0.3 AUD added for calves over 90 days of age, esophageal steers $=0.8$ AUD, bulls $=1.2$ AUD (Waller et al. 1986).

${ }^{c}$ Dates were the same in both 1986 and 1987.

Cows were of 2 types, either high or low milk producers. The low producing cows were selected from a Hereford population. The high producing cows were selected from the F2 generation of a composite breed and represented 2 breed types. All high producing cows were $1 / 2$ red Angus with the other half being either Tarentaise or Charolais (Table 1). Calving began 21 Mar. 1986 and 29 Mar. 1987.

Cows and calves were weighed and cows' body condition scored at the beginning of grazing, at the beginning and end of the breeding season, and at weaning (see Table 1). Body condition scores were based on a palpated determination of fleshing over the ribs and thoracic vertebrae (Bellows et al. 1971). Body condition was scored from 1 (thinnest) to 10 (fattest).

Before the breeding season, estrus was determined using sterile bulls fitted with grease marking harnesses. In both years, sterile bulls were placed with the cows on 8 June and all cows were checked daily for estrus. On 19 June, sterile bulls were removed and the ovaries of cows that had not been detected in standing estrus were palpated for a corpus luteum. A palpable corpus luteum was considered evidence that a cow had been in estrus at least once. A fertile 2-yr-old Hereford bull was placed with the cows in each replicate during the breeding season. Cows were pregnancy tested by rectal palpation at weaning.

Twelve-hour milk production estimates for each cow were determined 4 times each year (Table 1) by the calf weigh-suckleweigh technique as described by Adams et al. (1989).

Forage diets were collected from esophageal-fistulated steers (4 steers/replicate) 5 times each year (Table 1). After an overnight fast, forage samples were collected from the fistula of each steer following a 30 - to 45 -min grazing period. Fistula-forage samples were dried at $45^{\circ} \mathrm{C}$ and ground through a $1-\mathrm{mm}$ screen in a Wiley mill. Fistula-forage samples were analyzed for kjeldahl nitrogen, organic matter by standard methods (AOAC 1984), and for neutral detergent fiber (NDF) and acid detergent fiber (ADF), according to Goering and Van Soest (1970).

Data were analyzed as a split plot with range type, year, and grazing treatment $X$ year as the main plot; error term for the main plot was replicate (range type $X$ year). Cow type, breed type, cow type $X$ range type, and cow type $X$ year were the subplot and were tested by the residual. Other interactions were included in the model but were nonsignificant and were deleted.

\section{Results and Discussion}

Annual precipitation (October through September) was $114 \%$ and $95 \%$ of the long-term average for 1986 and 1987 , respectively (Table 2). Precipitation for April through August was $111 \%$ and $124 \%$ of the long-term average, respectively.

Table 2. Monthly and annual precipitation for 1986 and 1987 at Miles City, Mont.

\begin{tabular}{|c|c|c|c|c|c|c|c|}
\hline Year & Apr. & May & Jun. & Jul. & Aug. & Total $^{\mathrm{a}}$ & $\begin{array}{l}\text { Total for } \\
\text { year }\end{array}$ \\
\hline & \multicolumn{7}{|c|}{ 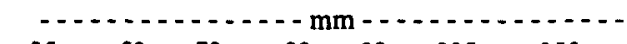 } \\
\hline Long term & 35 & 59 & 70 & 39 & 32 & 235 & 355 \\
\hline 1986 & 30 & 84 & 54 & 42 & 52 & 262 & 406 \\
\hline 1987 & 4 & 109 & 26 & 101 & 47 & 287 & 339 \\
\hline
\end{tabular}

'Total April through August.

Composition of fistula-forage samples was affected by day and year collected (Figs. 1 and 2). Interactions between range type, day of collection and year were significant $(P<0.05$ to $P<0.01)$. Differences for crude protein and ADF within day and between range types were generally nonsignificant. Some differences within year, day, and treatment occurred for NDF. Dietary crude protein was near or above $12 \%$ in May and June both years, but was generally between $6 \%$ and $8 \%$ in July, August, and September for both seeded and native range.

Change in body weight and body condition scores from the end of breeding season to weaning were the only traits showing significant differences due to breed type (i.e., breed type within high milking cows) differences were $3.6 \mathrm{~kg}$ and 0.1 body condition scores, respectively. All other breed type effects were nonsignificant $(P>0.05)$; also no interactions with breed type occurred, therefore, breed type data are not presented.

As expected, high producing cows gave more $(P<0.05)$ milk at sampling dates than low producing cows, regardless of range type (Table 3). Milk production of high producing cows on 14 Sep-

Table 3. Least square means for 12 -hour milk production of 2 types of beef cows (i.e. high or low milk production) grazing native of seeded rangeland near Miles City, Mont.

\begin{tabular}{|c|c|c|c|c|}
\hline \multirow[b]{2}{*}{ Date } & \multicolumn{2}{|c|}{ Cow type } & \multicolumn{2}{|c|}{ Range type } \\
\hline & High & Low ${ }^{a}$ & Native & Seeded \\
\hline & - & $-\mathbf{k g}-$ & $\cdots$ & \\
\hline 28 May & $5.3^{* *}$ & 3.5 & & \\
\hline 18 Jun. & $4.8^{* *}$ & 3.2 & & \\
\hline 1 Aug. & $4.0^{* *}$ & 2.3 & $3.5^{* *}$ & 2.8 \\
\hline 14 Sept. & $3.1^{* *}$ & 1.8 & & \\
\hline
\end{tabular}

"All range type and year effects and all interactions were nonsignificant $P>0.05$, except for the range type effect on 1 Aug. and the year effective on 14 Sept. Milk production 14 Sept. $1986=2.0 \mathrm{~kg} ; 1987=3.0 \mathrm{~kg}$, means were different $P<0.01$.

* Means are different $P<0.01$. 


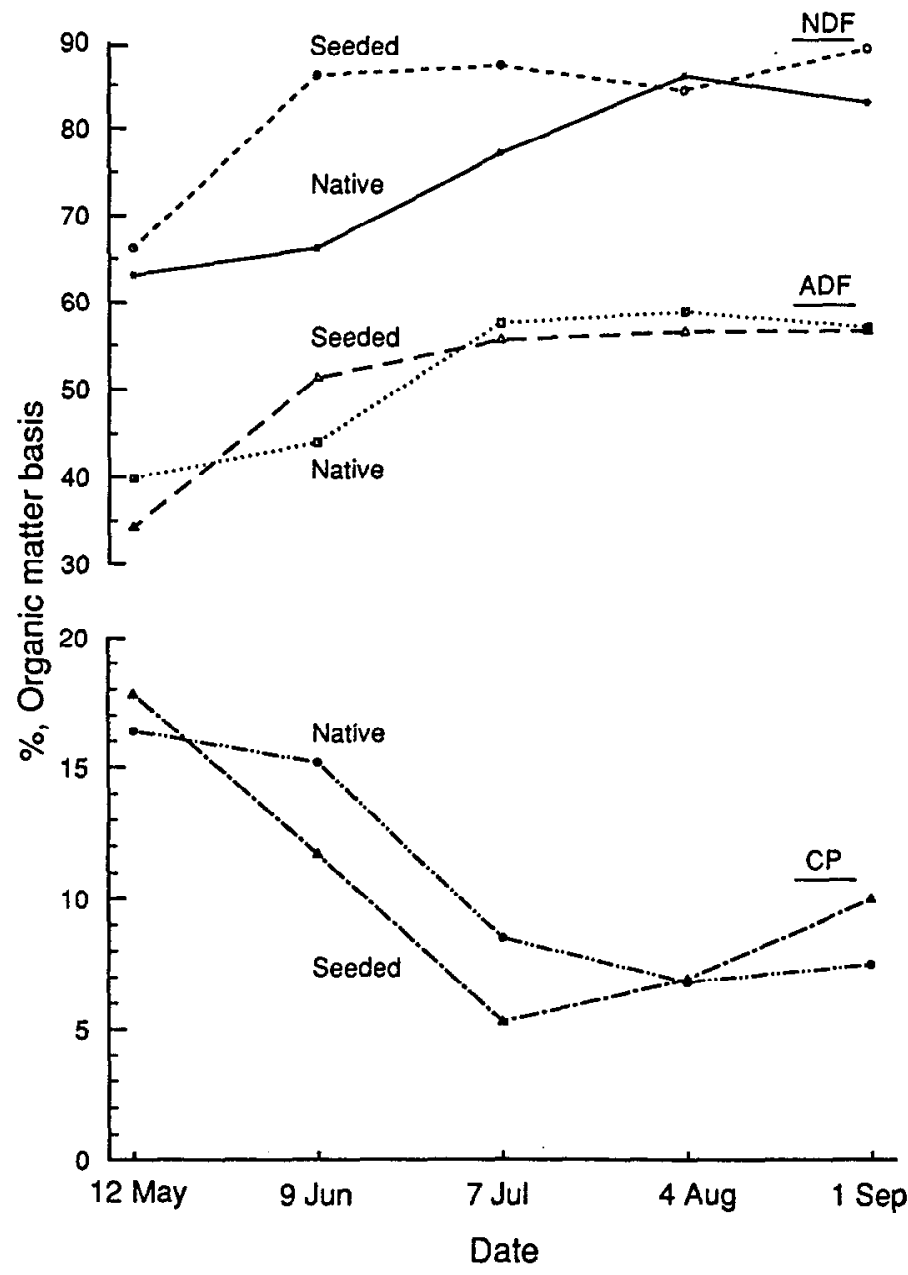

Fig. 1. Acid detergent fiber (ADF), neutral detergent fiber (NDF), and crude protein content of diets collected from esophageally fistulated steers grazing native or seeded rangeland during 1986.

tember was nearly as high as low producing cows in May or June. May and June milk production was not influenced by range type, year, or any interactions. August milk production was greater $(P<0.01)$ for cows grazing native range than for those grazing seeded range. September milk production was greater $(P>0.01)$ in 1987 than 1986. All interactions involving year, range type, and cow type for August and September milk production were nonsignificant.

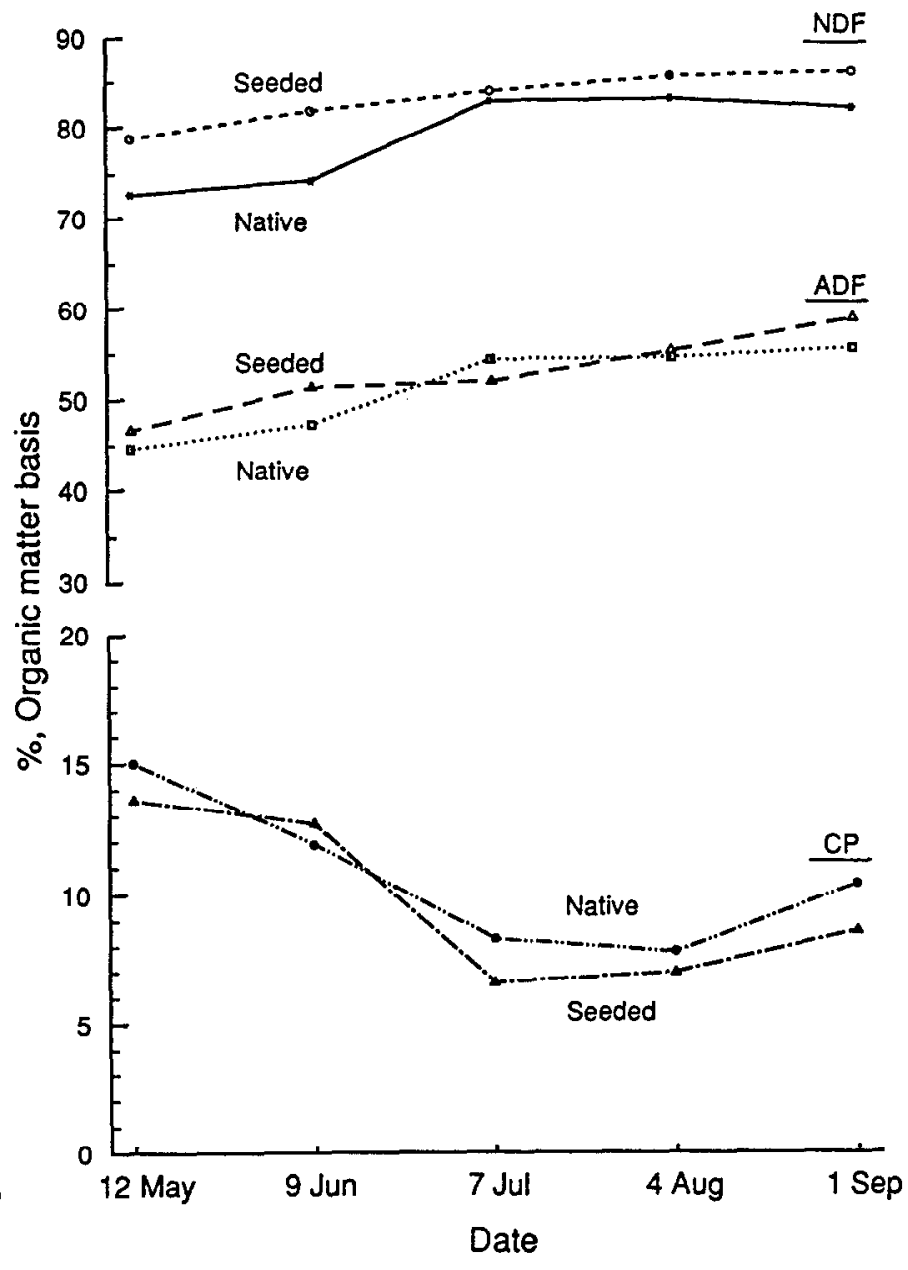

Fig. 2. Acid detergent fiber (ADF), neutral detergent fiber (NDF), and crude protein content of diets collected from esophageally fistulated steers grazing native or seeded rangeland during 1987.

Percentage of cows cycling at the beginning of the breeding season and fall pregnancy rate was not affected $(P>0.05)$ by range type, cow type, year, or any interactions. Pregnancy rate was $90.7 \%$ for the 2 years and $89.0 \%$ of cows were cycling at the beginning of the breeding season both years (Table 3). Both high and low producing cows were in moderate body condition after calving, and both types of cows gained weight and body condition from the initiation of grazing to the beginning of the breeding season. The

Table 4. Least squares means for beginning body condition score and change in body condition score of 2 types of beef cows (i.e. high or low milk production) grazing native or seeded rangeland near Miles City, Mont.

\begin{tabular}{|c|c|c|c|c|c|c|}
\hline \multirow[b]{2}{*}{ Trait } & \multicolumn{2}{|c|}{ Cow type ${ }^{\mathrm{a}}$} & \multicolumn{2}{|c|}{ Range type } & \multicolumn{2}{|c|}{ Year } \\
\hline & High & Low & Native & Seeded & 1986 & 1987 \\
\hline Beginning body condition score & $5.91^{* *}$ & 5.30 & $\begin{aligned}- \text { Body } \\
5.54\end{aligned}$ & 5.67 & 5.51 & 5.70 \\
\hline $\begin{array}{l}\text { Change from on pasture to beginning of } \\
\text { breeding season ( } 63 \text { days) }\end{array}$ & $0.27^{* *}$ & 0.59 & 0.37 & 0.39 & $0.65^{* *}$ & 0.22 \\
\hline Change during breeding season (49 days) & $-0.24^{* *}$ & -0.03 & -0.03 & -0.24 & -0.08 & -0.19 \\
\hline $\begin{array}{l}\text { Change end of breeding season to weaning } \\
\text { (46 days) }\end{array}$ & $-0.96 * *$ & -0.08 & -0.75 & -0.26 & $-1.04 * *$ & 0.18 \\
\hline $\begin{array}{l}\text { Change from on pasture to weaning } \\
\text { (158 days) }\end{array}$ & $-0.96^{* *}$ & 0.60 & -0.40 & 0.01 & -0.29 & 0.12 \\
\hline
\end{tabular}

Interactions with cow type, range type, and year were nonsignificant $P>0.05$, except for cow type $\times$ year for change on pasture to weaning; means were: 1986 , high producing cows $=1.50$, low producing cows $=0.70 ; 1987$, high producing cows $=-0.38$, low producing cows $=0.85$.

cows $=1.50$, low producing cows 
Table 5. Least squares means for beginning body weight and change in body weight of 2 types of beef cows (i.e. high or low milk production) grazing native or seeded rangeland near Miles City, Mont.

\begin{tabular}{|c|c|c|c|c|c|c|}
\hline \multirow[b]{2}{*}{ Trait } & \multicolumn{2}{|c|}{ Cow type } & \multicolumn{2}{|c|}{ Range type } & \multicolumn{2}{|c|}{ Year } \\
\hline & High & Low & Native & Seeded & 1986 & 1987 \\
\hline Beginning body weight & $555.4^{* *}$ & 475.9 & $506.9^{* *}$ & 527.5 & 509.4 & 521.9 \\
\hline $\begin{array}{l}\text { Gain from on pasture to beginning of } \\
\text { breeding season ( } 63 \text { days) }\end{array}$ & $20.5^{* *}$ & 28.6 & 22.6 & 26.5 & $55.0^{* *}$ & -5.9 \\
\hline Gain during breeding season ( 49 days) & 20.9 & 22.0 & $30.9^{* *}$ & 12.0 & $-11.9 * *$ & 54.8 \\
\hline $\begin{array}{l}\text { Gain end of breeding season to weaning } \\
\text { ( } 46 \text { days) }\end{array}$ & -39.0 & -21.5 & -32.7 & -27.8 & -41.9 & -18.5 \\
\hline Gain from on pasture to weaning ( 158 days) & $2.5^{* *}$ & 29.2 & 20.9 & 10.8 & $1.2^{*}$ & 30.5 \\
\hline
\end{tabular}

Anteractions with cow type, range type, and year were nonsignificant $P>0.05$, except for cow type $\times$ year, for gain from on pasture to weaning which was significant $(P<0.01)$. "Interactions with cow type, range type, and year were nonsignificant $P>0.05$, except for cow type $\times$ year, for gain from on pasture to weaning $=126.5$,

Mcans were: 1986 , high producin
* Means are different $P<0.05$.
* Means are different $P<0.01$.

low producing cows gained more $(P<0.01)$ weight and body condition before breeding than did high producing cows. Moderate body condition at calving and maintenance of body condition until start of the breeding season are essential to achieve high pregnancy rates (Richards et al. 1986).

Body condition scores and body weight, along with their seasonal changes, are shown in Tables 4 and 5. Although both cows with high and low milk production gained body weight during the breeding season, body condition scores for both high and low producing cows were reflective of cows near maintenance. Both high and low producing cows lost body weight and body condition between the end of the breeding season and weaning, but loss of body condition was greater $(P<0.01)$ for cows with high milk production. Loss of body weight after the breeding season was not affected by year or range treatment. Change in body condition after the breeding season was greater $(P<0.01)$ during 1986 than 1987. Apparently, native or seeded rangeland would support only the maintenance requirement of a low milk-producing cow after the breeding season in the late summer, which is consistent with other research on the Northern Great Plains (Adams et al. 1989). Low dietary protein may have been a factor limiting production during late summer in this study. About $1,150 \mathrm{~g}$ of crude protein are required to support $7.5 \mathrm{~kg}$ daily milk production by $550-\mathrm{kg}$ cows (NRC 1984). During late summer the high producing cows would have needed to consume $16.4 \mathrm{~kg}$ of organic matter daily containing $7 \%$ crude protein to support the observed milk production in Table 3. This level would be nearly $3 \%$ of body weight and may be unrealistic based on other work at this location (Adams et al. 1987a, Ward et al. 1990). Dietary energy seems less likely to be limiting than does crude protein (Adams and Short 1987). Weaning date may be critical for cows with high milk production to ensure that they do not become thin before the fall-winter grazing period. Weaning the calf would reduce the cow's nutrient requirement and prevent loss of body weight or body condition. Cows which enter the winter grazing period in low body condition are likely to be thin in the spring (Adams et al. 1987b). Cows that are thin at calving will breed later in the breeding season or not at all (Richards et al. 1986). Change in body weight and body condition score from beginning of grazing in April through weaning in September was not influenced by range type, but a cow type $X$ year interaction occurred $(P<0.01)$. During the fall grazing period, high producing cows gained less weight and lost more body condition compared to low producing cows during 1986 and 1987, but differences were smaller in 1987 than 1986. Late summer and early fall appears to be a critical period for high producing cows.

Steer calves gained more body weight $(P<0.01)$ during each period and overall than did heifers. All sex of calf interactions with year, cow type, and forage type were nonsignificant $(P>0.05)$;

Table 6. Least squares means for body weight gains of calves from 2 types of beef cows (i.e. high or low milk production) grazing native or seeded rangeland near Miles City, Mont.

\begin{tabular}{|c|c|c|c|c|c|c|}
\hline \multirow[b]{2}{*}{ Trait $^{b}$} & \multicolumn{2}{|c|}{ Cow type } & \multicolumn{2}{|c|}{ Range type } & \multicolumn{2}{|c|}{ Year } \\
\hline & High & Low & Native & Seeded & 1986 & 1987 \\
\hline Birth weight & $39.2^{* *}$ & 35.0 & 36.6 & 37.7 & 38.3 & 36.0 \\
\hline $\begin{array}{l}\text { Gain from on pasture to beginning } \\
\text { of breeding season ( } 63 \text { days) }\end{array}$ & $56.2^{* *}$ & 40.2 & 49.6 & 46.8 & 49.1 & 47.2 \\
\hline Gain during breeding season ( 49 days) & $55.0^{* *}$ & 37.7 & $49.0^{*}$ & 43.7 & 46.6 & 46.1 \\
\hline $\begin{array}{l}\text { Gain end of breeding season to weaning } \\
\text { (46 days) }\end{array}$ & $46.3^{* *}$ & 35.0 & 42.1 & 39.1 & $26.2^{* *}$ & 55.1 \\
\hline $\begin{array}{l}\text { Gain from on pasture to weaning } \\
\text { (158 days) }\end{array}$ & $157.5^{* *}$ & 112.9 & 140.8 & 129.6 & $121.9 * *$ & 148.5 \\
\hline
\end{tabular}

"Interactions with cow type, range type, and year were nonsignificant $P>0.05$, except: cow type $\times$ year interaction for gains on pasture to beginning of the breeding season (means were 1986 - high producing cows $=58.8$ and low producing cows $=39.5,1987$ - high producing cows $=53.6$ and low producing cows $=40.9$ ); cow type $\times$ year for gains from end of breeding season to weaning (means were 1986 - high producing cows $=30.0$ and low producing cows $=22.9,1987-$ high producing cows $=62.6$ and low producing cows $=$ 47.6); and range type $X$ year for gain on pasture to weaning (means were 1986 native $=37.7$, seeded $=38.9$ and 1987 native $=35.5$, seeded $=36.4$ ).

'Sex of calf was included in the model. Steer calves gained more weight than heifer calves during each period, but all sex of calf interactions were nonsignificant; therefore, data are combined for male and female calves.

* Means are different $P<0.05$.

* Means are different $P<0.05$. 
therefore, data were combined and mean gain presented in Table 6. Calves gained more $(P<0.05)$ body weight during the breeding season while grazing native range than seeded range, but total gains from the beginning of spring grazing until weaning were similar $(P>0.05)$ for both native and seeded rangeland. Calf gains from beginning of spring grazing to weaning were greater $(P<0.01)$ during 1987 than 1986 . Interactions with cow type and range type were generally not significant $(P>0.05$ ) for calf gains. Calves from high producing cows were heavier at birth and gained more weight during each period $(P<0.01)$ than calves from low producing cows.

\section{Conclusions}

We concluded that cows with high or low milk production and their calves performed similarly on native and seeded rangeland. Nutrient intake from both seeded and native rangeland was inadequate to support lactation and maintenance for high producing cows during late summer. Crude protein appears to be a limiting nutrient for lactating cows grazing Northern Great Plains during the late summer. Date of weaning may be an important consideration for high producing cows to ensure adequate body condition for winter and next year's reproduction of the cow.

\section{Literature Cited}

Adams, D.C., R.C. Cochran, and P.O. Currie. 1987a. Forage maturity effects on rumen fermentation, fluid flow, and intake of grazing steers. J. Range Manage. 40:404-408.

Adams, D.C., and R.E. Short. 1987. The role of animal nutrition on productivity in a range environment. p. 37-43. In: R.S. White and R.E. Short (eds.), Achieving efficient use of rangeland resources. Proc. Fort Keogh Res. Symp., Miles City, Mont.

Adams, D.C., R.E. Short, and B.W. Knapp. 1987b. Body size and body condition effects on performance of grazing beef cows. Nutr. Rep. International. 35:269-277.
Adams, D.C., R.B. Staigmiller, and B.W. Knapp. 1989. Beef production from native and seeded Northern Great Plains ranges. J. Range Manage. 42:243-247.

AOAC. 1984. Official methods of analysis (14th ed.). Assoc. Official Anal. Chem. Washington, D.C.

Bellows, R.A., R.E. Short, D.C. Anderson, B.W. Knapp, and O.F. Pahnish. 1971. Cause and effect relationships associated with calving difficulty and birth weight. J. Anim. Sci. 33:407-415.

Currie, P.O., and D.R. Smith. 1970. Response of seeded ranges to different grazing intensities in the Ponderosa Pine zone of Colorado. USDA Forest Serv. Prod. Res. Rep. 112

Goering, H.K., and P.J. VanSoest. 1970. Forage fiber analysis. ARS, USDA Agr. Handb. 379.

Hart, R.H., J.W. Waggoner, D.H. Clark, C.C. Kaltenback, J.A. Hager, and M.B. Marshall. 1983. Beef cattle performance on crested wheatgrass plus native range vs. native range alone. J. Range Manage. 36:38-40.

Houston, W.R., and J.J. Urick. 1972. Improved spring pastures, cow-calf production, and stocking rate carryover in the Northern Great Plains. USDA, Agr. Res. Serv. Tech. Bull. 1451:1-21.

NRC. 1984. Nutrient requirements of beef cattle. (6th rev. ed.) Nat. Acad. Sci., Nat. Res. Counc. Washington, D.C.

Richards, M.W., J.C. Spltzer, and M.B. Warner. 1986. Effect of varying levels of postpartum nutrition and body condition at calving on subsequent reproductive performance in beef cattle. J. Anim. Sci. 62:300-306.

Waller, S.S., L.E. Moser, and B. Anderson. 1986. A guide for planning and analyzing a year-round forage program. Univ. of Nebraska Ext. Serv. Ec 86-113. Lincoln, Neb.

Ward, M.G., D.C. Adams, J.D. Wallace, M.L. Galyean, and B.W. Knapp. 1990. Supplementation and monensin effects on digesta kinetics. I. Cattle grazing summer range. J. Range Manage. 43:378-382.

Wight, J.R., C.K. Gee, and R.J. Kartchner. 1983. Integrated rangeland and cropland management, p. 435-459. In: Dryland Agr. Agron. Monogr. 23. Amer. Soc. Agron. Madison, Wisc. 